\title{
Telematics in underground mining
}

\begin{abstract}
Telematics denotes new telecommunication functions connected with the informatics domain. In this paper, these issues have been referred to selected telecommunication and informatics systems applied in Polish mining plants. Using a DGT IPnova telecommunication server as an example, a teleinformatic network was presented in an all-plant communication network. In this aspect, selected dispatcher monitoring systems of the basic engineering processes in underground mines were discussed, paying attention to the fact that a fiber-optic network shall contribute to telematic system development.
\end{abstract}

Key words: mining telematics, mining telecommunication systems, monitoring of machines and devices

\section{INTRODUCTION}

The word "telecommunication" (in French: télécommunication) was used for the first time in the book of French engineer Édouarda Estaunié entitled "Traité pratique de télécommunication électrique", published more than 110 years ago [1]. Since that time, several dozen expressions have appeared in which this Greek prefix tele ("distant," "far away") occurs. Today, we frequently use such concepts as telephone, teletransmission, telemetry, telecontrol, television, and teletechnique. Some of them drop from common use (for instance: telegram (cablegram) or, due to the huge development of contemporary telecommunication, are substituted with several new expressions (for instance, teleelectrics).

The contemporary definition of telecommunication included in the Polish Telecommunication law [2] denotes broadcast, reception, or transmission of information (whatever it is) using cables, radio, or optic waves or other means by applying electromagnetic energy. Thus, telecommunication is a domain of science and technique as well as human activities related to the distant transmission of messages by means of electrical signals through telecommunication channels (Fig. 1).

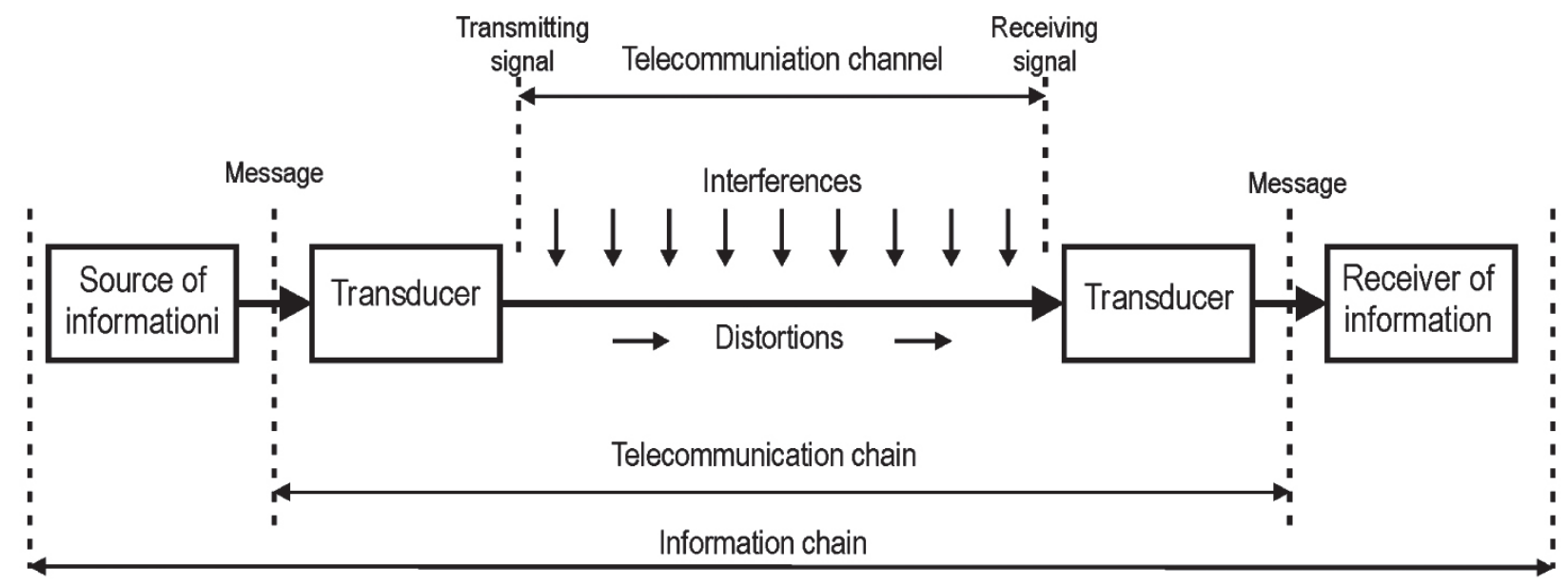

Fig. 1. Telecommunication and information chain 
The development of computer engineering and necessity to transmit related information between computers led to the creation of the concept of teleinformatics [3]. At the turn of the 20th century, the abbreviated expression spread (i.e., telematics). Making an analysis of the various cases of the usage of the concept "telematics," we may find that it is used as follows [4]:

- in relation to the structural solutions in which electronic acquisition and processing information make the integral elements of a telecommunication system,

- in relation to the technical solutions that integrate telecommunication and informatics systems.

Thus, telematics is the determination of new telecommunication functions connected with the informatics domain. Due to the various applications of informatics in the technique, this expression appears together with an adjective that determines the application domain; for instance, telematics of transport and medical or industrial telematics. Mining telematics are informatics systems that are applied in solutions for mining, integrating telecommunication with the informatics applied to these systems.

\section{MINING TELECOMMUNICATION SYSTEM}

In order to connect an information source with an information receiver, we create an information chain (and inside it, a telecommunication chain) (Fig. 1) in which a mining telecommunication server plays an important role. Information sources are most-frequently physical magnitudes that, in a processing apparatus, are changed into signals entered to a transmission channel utilizing an appropriate medium.

In underground mining works, a transmission channel may use the transmission media as follows:

- symmetric copper cables and leakage feeders [5],

- fiber-optic cables [6],

- electromagnetic waves (in mining radiocommunication) [5],

- signaling cores in cutter-loaders cables (for instance, the $\mathrm{SMoK}^{1}$ system) [7].

A transmission channel may contain several sections utilizing various media and transmission devices.

\footnotetext{
1 Abbreviated name: system monitorowania kombajnów [loader and cutter monitoring system] of SOMAR company.
}

A signal from the output of the transmission channel is converted in the processing apparatus to a message useful for the receiving person.

Telecommunication systems in mines most-frequently execute services of cable communication (telephone, alarm, loudspeakers) [1] or radio communication. Besides voice communication services within the recent years in underground mining works, one can observe a large development of other services (mostly teleinformatic services), which are listed in Table 1 [6].

In all services accomplished by telecommunication systems operating in mines, solutions are applied that are used appropriately for informatic systems. Figure 2 presents a simplified block diagram of a telecommunication system of an underground mine [8]. Making an analysis of this drawing, we may notice that information about most underground telecommunication systems is collected, processed, and then visualized in the servers of plant dispatcher rooms. In general, we may state that a mining telecommunication system accomplishes its services connected with voice communication (left side of Fig. 2) as well as being appropriate for teleinformatic systems supervised by servers that visualize the engineering processes on monitors (M) in plant dispatcher rooms and other decision spots of a mine. The arrows in this drawing present the basic direction of information flow.

The separate symbols in systems connected with mining communication denote the following:

- telephones (T) and telephone-signaling devices (TS),

- radio-telephones (RT),

- loudspeaker devices (UG),

- panels of dispatcher and alarm communication (PD, PA),

whereas information sources appropriate for teleinformatic systems are as follows:

- gasometry meters (MG), methane detectors (CH4), and mine station (SD) of these systems together with execution elements whose basic task is to switch off the electric power supply of hazardous areas $(\mathrm{Wz})$,

- geophones (G) and seismometers (S) of mining geophysics systems,

- cameras $(\mathrm{K})$ of vision monitoring systems,

- channel transmitter (NK) of transmission systems (mainly bi-stable signals),

- controllers (PLC) in basic mining machines,

- digital protection in underground medium voltage switch bays ( $\mathrm{SN})$. 
Table 1

Teleinformatic services executed by telecommunication system in mines

\begin{tabular}{|c|c|}
\hline $\begin{array}{l}\text { Executed } \\
\text { service }\end{array}$ & Characteristics \\
\hline $\begin{array}{l}\text { Telemetry } \\
\text { (gasometry) }\end{array}$ & $\begin{array}{l}\text { These are mostly telemetric systems that monitor mining atmosphere condition and automatically switch } \\
\text { off electrical devices in case of danger. As subscriber devices in these systems, methane detectors are } \\
\text { applied as well as meters of carbon monoxide, air velocity, temperature, pressure difference, etc. }\end{array}$ \\
\hline $\begin{array}{l}\text { Bi-stable signal } \\
\text { transmission }\end{array}$ & $\begin{array}{l}\text { In these systems (for instance, FOD) transmission (with one subscriber pair), it is possible to } 30 \text { bi-stable infor- } \\
\text { mations from signal sources (sensors, contacts) dissipated in various headings. These systems monitor operation } \\
\text { conditions even several hundred mining devices. }\end{array}$ \\
\hline $\begin{array}{l}\text { Monitoring } \\
\text { (television) }\end{array}$ & $\begin{array}{l}\text { Monitoring (preview) of important mining devices as well as headings (shaft bottom, stations, transfer points). } \\
\text { These systems use cameras and optical fiber networks. }\end{array}$ \\
\hline $\begin{array}{l}\text { Monitoring } \\
\text { (of parameters } \\
\text { of machines } \\
\text { and devices) }\end{array}$ & $\begin{array}{l}\text { In mines, basic machines and mining devices are monitored. Data from these devices could be transmitted } \\
\text { to the surface while using: } \\
\text { - modem transmission in copper cables (for instance, SMoK system), } \\
\text { - optical fiber networks, } \\
\text { - leaky feeders, radio communication systems. } \\
\text { Data from the servers of these systems are backed-up and then visualized in dispatcher rooms and other } \\
\text { decisive spots of a mine. }\end{array}$ \\
\hline $\begin{array}{l}\text { Monitoring } \\
\text { (localization, } \\
\text { identification) }\end{array}$ & $\begin{array}{l}\text { Systems that execute these services make possible zone localization as well as identification of persons equipped } \\
\text { with personal identifiers or machines (among others). } \\
\text { Localization together with identification is accomplished by identifier readers arranged in specified spots } \\
\text { of the headings. }\end{array}$ \\
\hline $\begin{array}{l}\text { Visualization } \\
\text { (of engineering } \\
\text { processes) }\end{array}$ & $\begin{array}{l}\text { Visualization analysis (i.e., graphic methods of creation) and transferring information about selected } \\
\text { engineering processes are accomplished by the use of the following: } \\
\text { - mosaic synoptic tables in plant dispatcher rooms; light elements of these tables are controlled from } \\
\text { a bi-stable signal transmission system, } \\
\text { - computer monitoring and visualization systems of engineering processes; data is made available by visualization } \\
\text { systems dedicated for mines (for instance, ZEFIR, SAURON, THOR, etc.) using SCADA }{ }^{2} \text { software. }\end{array}$ \\
\hline
\end{tabular}

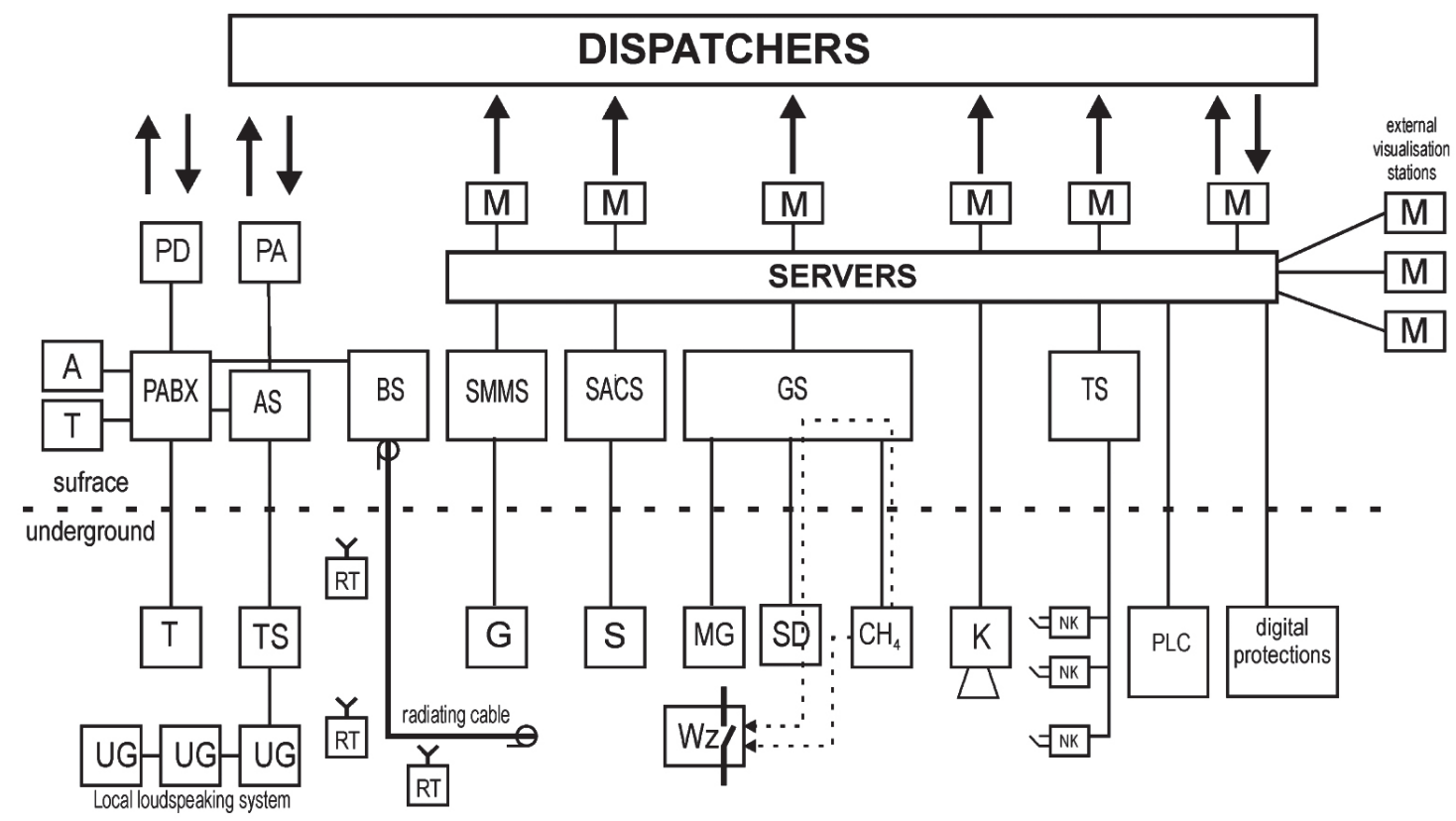

Fig. 2. Simplified diagram of standard telecommunication system of underground mines. PABX-private automatic branch exchange, $A S$ - dispatch alarm station, $B S$ - base station for radiocommunication system with radiating cable, SMMS - seismometric station, SACS - seismoacoustic station, GS - gasometric station,

\section{TS - transmision station}

2 SCADA - English: supervisory control and data acquisition. 
Attention should be paid to the technical environment of mine undergrounds putting atypical requirements (restrictions) to telecommunication systems that, in fact, are represented in the design and structure of telematic systems in mines. Basic environment restrictions within the scope of the wider application of many new solutions applied in telematic systems are presented in Table 2 [9].

\section{TELEMATICS IN MINING TELEPHONE COMMUNICATION}

The basic function of every mining telephone exchange is to create an opportunity to switch the subscribers' terminals connected to it. An increase in digital telephone exchange functionality as well as the alteration of regulations within this scope [10-12] caused a large expansion of their control part that led to the creation separated computer network that contained a series of computers, including the appropriate software executing such functions as recording conversations, voice mail, telephone book, automatic measurement of transmission lines, message dissipation, subscriber identification, registering and scaling of charges of telephone talks, database edition, etc. As a result of such an expansion, a telephone exchange became a telecommunication server because, despite the communication functions appropriate for telephone exchanges, they also accomplish many functions proper for informatic systems [13].

Telecommunication servers play a significant role in the integration processes of a communication system with alarm systems, gasometry, and connection of telecommunication servers of linked and multishift mines [6].

Table 2

Basic restrictions in using telematic systems in mines

\begin{tabular}{|c|c|}
\hline Restriction & Characteristics \\
\hline $\begin{array}{l}\text { Explosion-proofing } \\
\text { (anti-explosiveness) }\end{array}$ & $\begin{array}{l}\text { In mines with the increased threat of methane and/or coal dust explosions, the underground } \\
\text { devices and underground interfaces of the telecommunication lines should be explosion-proof. } \\
\text { Underground devices of telecommunication systems should have an intrinsically safe design } \\
\text { or optical safe (feature "op is" according to PN-EN 60079-28) that make it possible to operate } \\
\text { in any methane concentration. }\end{array}$ \\
\hline $\begin{array}{l}\text { Device housing protection } \\
\text { degree }\end{array}$ & $\begin{array}{l}\text { Due to humidity, salinity, and the presence of dust telecommunication devices as well as de- } \\
\text { vices that cooperate with these systems, the workings should have a minimum IP54 (Interna- } \\
\text { tional Protection Rating.) }\end{array}$ \\
\hline Structure of workings & $\begin{array}{l}\text { Small lateral dimensions of dog headings (several meters) in relation to their longitudinal } \\
\text { dimensions (up to several kilometers); extensiveness of headings and necessity to use tree } \\
\text { structure of telecommunication networks. }\end{array}$ \\
\hline Eletromagnetic environmen & $\begin{array}{l}\text { There is a large accumulation (in limited space) of network and electro-power devices of very } \\
\text { large power in headings; difficulties exist with the effective separation of electro-power } \\
\text { (including SUPO) and telecommunication earth electrodes; a telecommunication network } \\
\text { with armored cables as well as electro-power ones along long sections of headings run in } \\
\text { parallel within small distances should first of all be limited by the lateral dimensions of the } \\
\text { headings. }\end{array}$ \\
\hline $\begin{array}{l}\text { Limited continuity of power } \\
\text { supply of underground } \\
\text { telecommunication devices } \\
\text { of electro-power network }\end{array}$ & $\begin{array}{l}\text { The power supply continuity of devices is limited by: } \\
\text { - switching off in electro-power network according to plan (for instance, accomplishment of } \\
\text { repairs) as well as periodic testing the switching off systems of electro-power devices that are } \\
\text { performed by gasometric systems, } \\
\text { - unplanned shutdowns induced by the actuation of electro-power and methano-metric protec- } \\
\text { tions. } \\
\text { Exceeding the methane detector alarm threshold in a heading causes the automatic switching- } \\
\text {-off of the power supply in a given area. An increase in carbon monoxide concentration or lack } \\
\text { of minimum air flow could also be reasons for alarms or shutdowns of electric power. }\end{array}$ \\
\hline
\end{tabular}

Figure 3 presents a simplified block diagram of a single-section DGT IPnova telecommunication server, most frequently applied in Polish underground mining plants in which the simplest self-contained teleinformatic network LAN is marked. To the switch of this network, besides the control units (JS), the below-mentioned servers are connected to conversation recording system (NetCRR), additional services (SUD), 


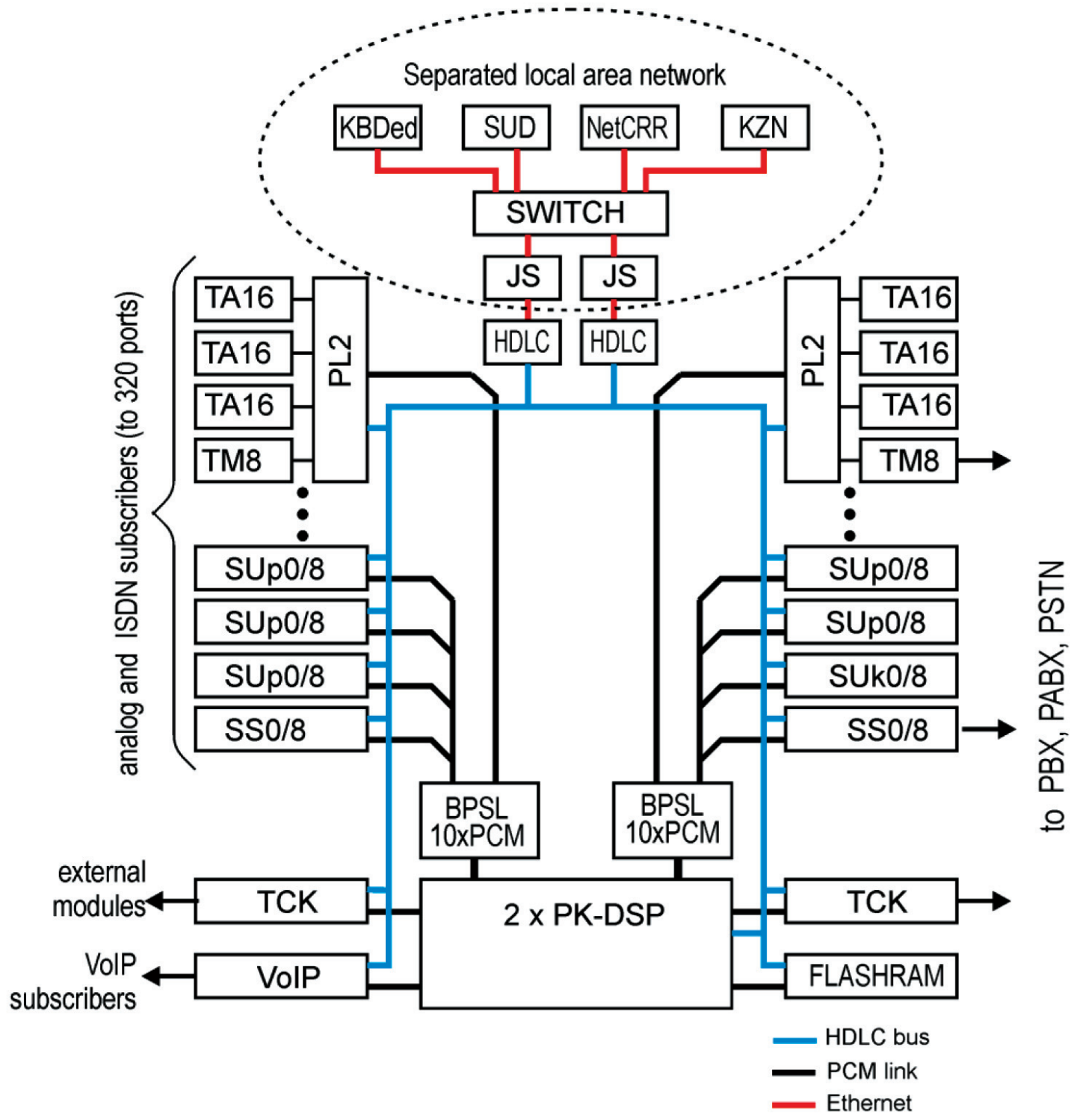

Fig. 3. General architecture of single-section DGT IPnova telecommunication server, PL2 line processors, PK-DSP - switching network FLASHRAM processors of tone signals and verbal messages, BPSL line buffer

database edition (KBDed), remote supervision (KZN), etc. This server may handle not only subscribers equipped with analogue telephones (TA16) or digital ones of various standards ( $\mathrm{SUp} 0, \mathrm{SS} 0, \mathrm{SUk} 0$ ) but also VoIP subscribers. The server in a LAN network may fulfill one of two basic informatic functions:

- within the scope of the hardware - these are industrial computers that render specified services, usually making available their resources for other computers or that intermediate in transferring data among computers,

- within the scope of the software - this specific software installed (program, database) that render services on behalf of other devices or systems (for instance, gasometric, visualization) connected to the same LAN network in a mine.
Usage of computer networks (abbreviated term $\operatorname{VoiP}^{3}$ ) is a relatively new method of executing telephone communication in mines. In this type of network, the transmission of packets exists that contain voice in a digital form. Contemporary telecommunication servers in mines make it possible to connect to an all-mine communication system; the VoIP telephony subscribers by means of a VoIP card furnished with an Ethernet interface. To the self-contained LAN network (or the digital ports of the DGT IPnova telecommunication server), teletransmission devices could be connected to other telecommunication systems (gasometry, data transmission, visualization, alarms).

\footnotetext{
3 VoiP $=$ Voice over Internet Protocol
} 


\section{TELEMATICS IN MONITORING SYSTEMS}

The first monitoring systems in underground mines have been executed for 40 years in methanometric dispatcher rooms (CTT63/40U exchanges). At the same time, the bi-stable monitoring of machines and mining devices became current (CTT-32 system). It had feature of observation of the so-called "extreme conditions": (for instance, operation/standstill, open/closed, full/not full, etc.) [7, 14]. For over twenty years, the combined cutter loader has been equipped with a computer control system together with event recording and a backup system. The remote monitoring of machines (from the surface) and mining devices commenced at the turn of the 20th century by implementing the SMoK system at the Bogdanka Mine, which uses modem system of information transmission to the dispatcher room of the plant. Thus, in dispatcher rooms of mines, there are two types of information on machine conditions or devices available:

- basic information - bi-stable monitoring gained most-frequently from systems of multiple signal transmission (for instance, FOD, UTS, CTT-32),

- advanced information (analog systems) - obtained from the controllers of mining machines and devices and also from digital protections in switch bays or from gasometric systems.

In ninetieth, the ZEFIR system became current, which was the first dispatcher room system of visualization using IBM PC personal computers operating under the control of a DOS system. At the beginning, this system collected data from a bi-stable transmission system and performed its visualization. ZEFIR (after many technical and program modifications) is in operation up to the present day, providing a lot of informal standards within the scope of the operation of computer monitoring systems and visualizations in mines [7].

At present, for the current supervision of machines and mining devices as well as electro-power networks, the monitoring systems are applied that mostfrequently use SCADA-type software. The basic tasks of such monitoring systems are as follows [6, 7, 14]:

- acquisition and backup of signals from devices being monitored (for instance, measurement results),

- visualization of condition of devices being monitored in supervision spots,

- remote control of machines and also control of switches in switch bays,

- alarming about the incorrectness of their condition,

- development of reports (for instance, for needs of manufacture supervision).
At present, copper symmetric cables are the basic transmission medium in underground mines. On average in a typical mine, over 1000 pairs are operated [7, 9]. This results from the fact that many terminal devices (methane detectors, telephones, and alarm-signaling devices) require a central power supply from the surface of the mine. In telematic systems, the acoustic frequency band is used for the transmission of bi-stable signal transmission (FOD-900, UTS), with access, by the way, in gasometry, where telephone modems are mainly utilized for leased lines, and in some systems frequency transmission (up to $12 \mathrm{kHz}$ ), in seisomometry and seismoacoustics as well as for monitoring machines and mining devices with the utilization of narrowband telephone modems for leased lines. Telephone modems in mines can operate with a flowability of up to $33,600 \mathrm{~kb} / \mathrm{s}$ in symmetric lines with a core diameter of $0.8 \mathrm{~mm}$.

Bands of higher frequency in underground mining plants could be operated in data transmission systems (for instance, as an RS485 interface or using Lon Works protocol; unfortunately for relatively short distances only [transmission range up to $2 \mathrm{~km}$ ], whereas in higher frequency bands, wideband modems are very rarely used (for instance, SHDSL modems made by the WESTERMO company) [15].

Restrictions connected with the widespread nature of workings necessary to provide intrinsic safety in underground teletransmission networks and maximum transmission velocities possible to obtain in copper cables caused that, in parallel to copper networks, the fiber-optic networks are constructed in mines are used first of all for monitoring systems of machines and mining devices.

The properties of the separate transmission media are specified in Table 3 [15].

Attention should be paid to the fact that contemporary telematics (i.e., IED) installed to it decides mostly of possible scope of machines and mining device monitoring. The presence of IED devices makes it possible, by measurement, to obtain much precise information about the values of measured electric magnitudes (current, voltage, power, electric energy) as well as allows for their remote control. Analysis of the present condition of the IED $^{4}$ devices installed in underground mines indicated that several various visualization systems are applied in parallel in mines. Some of them are used by the main dispatcher, others by the methanometry dispatcher, and still others are applied in energo-mechanic dispatcher rooms or used to control transportation.

Table 4 (in alphabetic order) presents the examples of dispatcher visualization systems used in Polish mines $[8,14]$.

\footnotetext{
4 IED - intelligent electronic devices.
} 
Table 3

Comparison of transmission media properties for underground mines

\begin{tabular}{|l|c|c|c|c|}
\cline { 2 - 5 } \multicolumn{1}{c|}{} & Symmetric copper cables & $\begin{array}{c}\text { Symmetric copper } \\
\text { leaky feeders }\end{array}$ & $\begin{array}{c}\text { Optical waveguide } \\
\text { cables }\end{array}$ & Radio connections \\
\hline Range & $\begin{array}{c}\text { from } 100 \mathrm{~m} \text { for } 1 \mathrm{~GB} / \mathrm{s}, \\
\text { up to over } 10 \mathrm{~km} \\
\text { for telephone band }\end{array}$ & $\begin{array}{c}\text { up to } 500 \mathrm{~m} \text {, necessity } \\
\text { to construct infrastructure } \\
\text { with repeaters }\end{array}$ & $\begin{array}{c}\text { up to several dozen } \\
\text { of } \mathrm{km}<1 \mathrm{~Gb} / \mathrm{s}\end{array}$ & $\begin{array}{c}\text { several hundred m, } \\
\text { access infrastructure } \\
\text { is necessary }\end{array}$ \\
\hline $\begin{array}{l}\text { Remote } \\
\text { power } \\
\text { supply }\end{array}$ & yes & yes & no; yes (hybrid cables) & no \\
\hline $\begin{array}{l}\text { Effect of } \\
\text { connections }\end{array}$ & negligible & small & significant & n.a. \\
\hline Flowability & $\begin{array}{c}\text { up to } 1 \mathrm{~Gb} / \mathrm{s} \text {, the higher } \\
\text { frequency the shorter range }\end{array}$ & $\begin{array}{c}\text { up to several hundred } \mathrm{MHz} \\
\text { (modems, wideband) }\end{array}$ & up to $1 \mathrm{~Gb} / \mathrm{s}$ & $\begin{array}{c}\text { up to several } \\
\text { dozen MB/s }\end{array}$ \\
\hline $\begin{array}{l}\text { Connection } \\
\text { engineering }\end{array}$ & easy & easy - requires interfaces & $\begin{array}{c}\text { difficult }- \text { requires } \\
\text { advanced tools } \\
\text { (fiber bonding) }\end{array}$ & n.a. \\
\hline
\end{tabular}

Table 4

Examples of systems for supervision, control and visualization applied in mines

\begin{tabular}{|c|c|c|}
\hline $\begin{array}{l}\text { System } \\
\text { name }\end{array}$ & $\begin{array}{l}\text { Manu- } \\
\text { facturer }\end{array}$ & Notes \\
\hline DEMKop & SOMAR & $\begin{array}{l}\text { Mining visualization system dedicated especially for energomechanic dispatcher rooms } \\
\text { of mining plants as tool software; hardware solution is SMoK system }\end{array}$ \\
\hline $\begin{array}{l}\text { e-kopalnia } \\
\text { (e-mine) }\end{array}$ & FAMUR & $\begin{array}{l}\text { Remote supervision system of mining machines (set of teleinformatic, hardware solutions, } \\
\text { and measurement tools). Elements of these system are: control devices (for instance, FAMAC: } \\
\text { MRS, OPTI, DMP), explosion-proof informatics hardware (for instance, server, LS local station, } \\
\text { MPC I computer), as well as diagnostic hardware and software systems. }\end{array}$ \\
\hline EMAC & $\begin{array}{l}\text { ENERGO } \\
\text { TEST }\end{array}$ & $\begin{array}{l}\text { System dedicated for electro-power networks; it cooperates with PLC controllers of electro-power } \\
\text { devices of various companies and with other protections provided with explicit communication protocol. }\end{array}$ \\
\hline EP7-SMP & ELPRO7 & Monitoring system for ELPRO underground pump station. \\
\hline $\begin{array}{l}\text { eSPiM } \\
\text { CSBiRE }\end{array}$ & WINUEL & $\begin{array}{l}\text { Electronic measurement and settlement system of energy; visualization reporting system, simulation, } \\
\text { and planning analysis as well as management of electric power consumption; applied in KGHM. }\end{array}$ \\
\hline MonSteer-D & Tranz-Tel & Dispatcher supervision system; tool software; hardware solution is, for instance, FOD system. \\
\hline SAURON & RNT & $\begin{array}{l}\text { SAURON visualization system has interfaces for communication with IED of mining devices } \\
\text { as well as dedicated software applications such as: Pumping station, } 6 \mathrm{kV} \text { grid, Haulage, } \\
\text { Longwalls, Mine faces, Skip hoists, Air conditioning. }\end{array}$ \\
\hline SD-2000 & EMAG & Dispatcher visualization system; tool software \\
\hline Smart Wall & $\begin{array}{l}\text { Elgór+ } \\
\text { Hansen }\end{array}$ & $\begin{array}{l}\text { Control, monitoring system of machines and mining devices. System is provided with hardware } \\
\text { elements (for instance, flame-proof EH-O/06 computer, EH-O/01 control panel, EH-O/03 separator) } \\
\text { as well as software (for instance, KESSA-ATON, EH-WallView, EH-MineView). }\end{array}$ \\
\hline SP3 & HASO & Industrial processes presentation system (SP3); tool software. \\
\hline $\mathrm{SW} \mu \mathrm{P}$ & HASO & Computer-aided system for dispatcher of methanometry; tool software. \\
\hline $\begin{array}{l}\text { SYNDIS } \\
(\mathrm{RV})\end{array}$ & $\begin{array}{l}\text { MIKRO } \\
\text { NIKA }\end{array}$ & $\begin{array}{l}\text { Supervision, consulting and control system for industrial installations; dispatcher monitoring } \\
\text { and control system of electro-power system operation of a mine is applied in KGHM. }\end{array}$ \\
\hline THOR & SEVITEL & Dispatcher system: visualization, monitoring, backup, reporting, and control; tool software. \\
\hline WIZAS & Becker Warkop & Visualization system of longwall machines with dedicated controllers of BECKER company. \\
\hline $\begin{array}{l}\text { WIZCON } \\
\text { Superwizor }\end{array}$ & $\begin{array}{l}\text { Wizcon }{ }^{\circledR} \\
\text { Systems } \\
\text { SABUR }\end{array}$ & $\begin{array}{l}\text { Dispatcher system for inspection of manufacture and safety parameters with WIZCON } \\
\text { visualization module; industrial software that allows management, monitoring, and control } \\
\text { of engineering processes using Internet browser. }\end{array}$ \\
\hline ZEFIR & PRUNELLA & $\begin{array}{l}\text { Most-frequently applied in mines, the dispatcher visualization system dedicated for plant } \\
\text { dispatcher room, dynamic synoptic table; tool software. }\end{array}$ \\
\hline
\end{tabular}




\section{SUMMARY}

At present, telematics in monitoring systems are developing the fastest among all other telecommunication services in mines. The monitoring of machines, devices, and the environment is always connected with the necessity to install new controllers as well as to modify the outfit and software of already-existing controllers, and also with construction of fiber-optic telecommunication lines in the cable network bus [15].

The implementation of monitoring to new engineering areas in mines should be, however, preceded with an analysis that would take into consideration both the telematics costs and its significance for the entire supervision of the engineering process in the mine or diagnostics of separate important devices.

Monitoring in a mine should be started from providing machines and mining devices with intelligent electronic devices (IED) and such automatic systems that make their remote control possible.

An increase of efficiency in a mine could be achieved with several methods. One of the most-advantageous methods to achieve this goal is:

- increase of effective operation time of machines and electrical devices operated in mining plant,

- minimization of standstills; i.e., time lost for uncontrolled failures of machines and devices as well as cutting down the time of interoperation duties (for instance, machine transfer).

These goals may be achieved by the implementation of modern telematic systems in mines. Unexpected failures should not occur in mines; thus, a special emphasis should be placed on monitoring the electrical devices mainly from the point of view of the earlier detection of incorrectness of their work as well as the proper preparation of any planned repairs.

One should realize that, due to the necessity to install telephone communication devices in headings, alarm system signaling devices and gasometric system sensors are copper cable and still shall be installed in all passages of underground headings. However, they cannot constitute the basic element of a teletransmission system in telematic systems. In order to monitor important energomechanic objects, the fiber-optic networks are to be utilized in mines.

\section{References}

[1] Miśkiewicz K., Wojaczek A.: Telekomunikacja w górnictwie. Systemy tączności telefonicznej, alarmowej i głośnomówiące, Wydawnictwo Politechniki Śląskiej, Gliwice 2018.

[2] Ustawa z dnia 16 lipca 2004 r. Prawo telekomunikacyjne. Dz.U. z 2004 r., nr 171 poz. 1800.

[3] Noris M.: Teleinformatyka, Wydawnictwo Komunikacji i Łączności, Warszawa 2002.

[4] Wydro K.B.: Telematyka - znaczenie $i$ definicje termi$n u$, "Telekomunikacja i techniki informacyjne" 2005, 1-2: 116-127.

[5] Miśkiewicz K., Wojaczek A.: Systemy radiokomunikacji z kablem promieniujacym, Wydawnictwo Politechniki Śląskiej, Gliwice 2010.

[6] Miśkiewicz K., Wojaczek A., Wojtas P.: Systemy dyspozytorskie kopalń podziemnych i ich integracja. Wybrane problemy, Wydawnictwo Politechniki Śląskiej, Gliwice 2011.

[7] Dyczko A., Wojaczek A. (red.): Systemy telekomunikacyj$n e$, monitoring $i$ wizualizacja podziemnej eksploatacji złóż, Monografia SEP. Wydawnictwo Fundacji dla AGH, Kraków 2011.

[8] Wojaczek A., Wojaczek A.: Systemy monitoringu w kopalni podziemnej, "Systemy Wspomagania w Inżynierii Produkcji" 2016, 1: 523-536.

[9] Wojaczek A.: Wpływ środowiska technicznego kopalń podziemnych na transmisje sygnałów $w$ dołowych sieciach telekomunikacyjnych, Wydawnictwo Politechniki Śląskiej, Gliwice 2014.

[10] Ustawa z dnia 9 czerwca 2011 r. Prawo geologiczne i górnicze. Obwieszczenie Marszałka Sejmu Rzeczypospolitej Polskiej z dnia 1 lipca 2016 r. w sprawie ogłoszenia jednolitego tekstu ustawy Prawo geologiczne i górnicze, Dz.U. z 2016 r., poz. 1131.

[11] Rozporzadzenie Ministra Energii z dnia 23 listopada 2016 r. $w$ sprawie szczegółowych wymagań dotyczacych prowadzenia ruchu podziemnych zakładów górniczych, Dz.U. z 2017 r., poz. 1118.

[12] Rozporzadzenie Rady Ministrów z dnia 30.04.2004 r. w sprawie dopuszczania wyrobów do stosowania w zakładach górniczych, Dz.U. z 2004 r., nr 99, poz. 1003.

[13] Wojaczek A.: Łacze, sieć serwer $w$ telekomunikacji górniczej, "Mechanizacja i Automatyzacja Górnictwa" 2014, 3: 53-59.

[14] Wojaczek A., Dyczko A. (red.): Monitoring wybranych procesów technologicznych w kopalniach podziemnych, Wydawnictwo Katedry Elektryfikacji i Automatyzacji Górnictwa Politechniki Śląskiej, Gliwice 2015.

[15] Wojaczek A., Miskiewicz K.: Problemy transmisji w kopalnianych systemach telekomunikacyjnych, "Mechanizacja i Automatyzacja Górnictwa" 2013, 7: 5-12.

ANTONI WOJACZEK, prof.

Department of Electrical Engineering and Automation in Industry

Faculty of Mining and Geology

Silesian University of Technology ul. Akademicka 2, 44-100 Gliwice, Poland awojaczek@polsl.pl 


\title{
Telematyka w podziemnych zakładach górniczych
}

\begin{abstract}
Telematyka to określenie nowych funkcji telekomunikacyjnych zwiazanych z dziedzina informatyki. $W$ artykule odniesiono te zagadnienia do wybranych systemów telekomunikacyjnych i informatycznych stosowanych $w$ polskich podziemnych zaktadach górniczych. Na przykładzie serwera telekomunikacyjnego DGT IPnova przedstawiono sieć teleinformatyczna $w$ systemie tączności ogólnozakładowej. W tym aspekcie omówiono również wybrane dyspozytorskie systemy monitorowania podstawowych procesów technologicznych $w$ kopalniach podziemnych, zwracając uwage na to, że o rozwoju systemów telematycznych decydować będą kopalniane sieci świattowodowe.
\end{abstract}

Słowa kluczowe: telematyka górnicza, kopalniane systemy telekomunikacyjne, monitoring maszyn i urządzeń

\section{WPROWADZENIE}

Słowo telekomunikacja (po francusku télécommunication) zostało po raz pierwszy użyte w książce francuskiego inżyniera Édouarda Estaunié Rozprawa praktyczna o telekomunikacji elektrycznej wydanej ponad 110 lat temu [1]. Od tego czasu pojawiło się kilkadziesiąt określeń, w których występuje ten grecki przedrostek „tele-” (na odległość, daleko), np.: telefon, teletransmisja, telemetria, telesterowanie, telewizja, teletechnika. Niektóre z nich wychodzą z powszechnego użytku (np. telegram) bądź w związku z ogromnym rozwojem współczesnej telekomunikacji są zastępowane przez kilka nowych określeń (np. teleelektryka).

Według współczesnej definicji zawartej w prawie telekomunikacyjnym [2], telekomunikacja to nadawanie, odbiór lub transmisja informacji (jakiejkolwiek natury) za pomocą przewodów, fal radiowych bądź optycznych lub innych środków wykorzystujących energię elektromagnetyczną. Telekomunikacja jest więc dziedziną nauki i techniki oraz działalności ludzkiej i dotyczy przesyłania wiadomości na odległość za pośrednictwem sygnałów elektrycznych kanałami telekomunikacyjnymi (rys. 1).

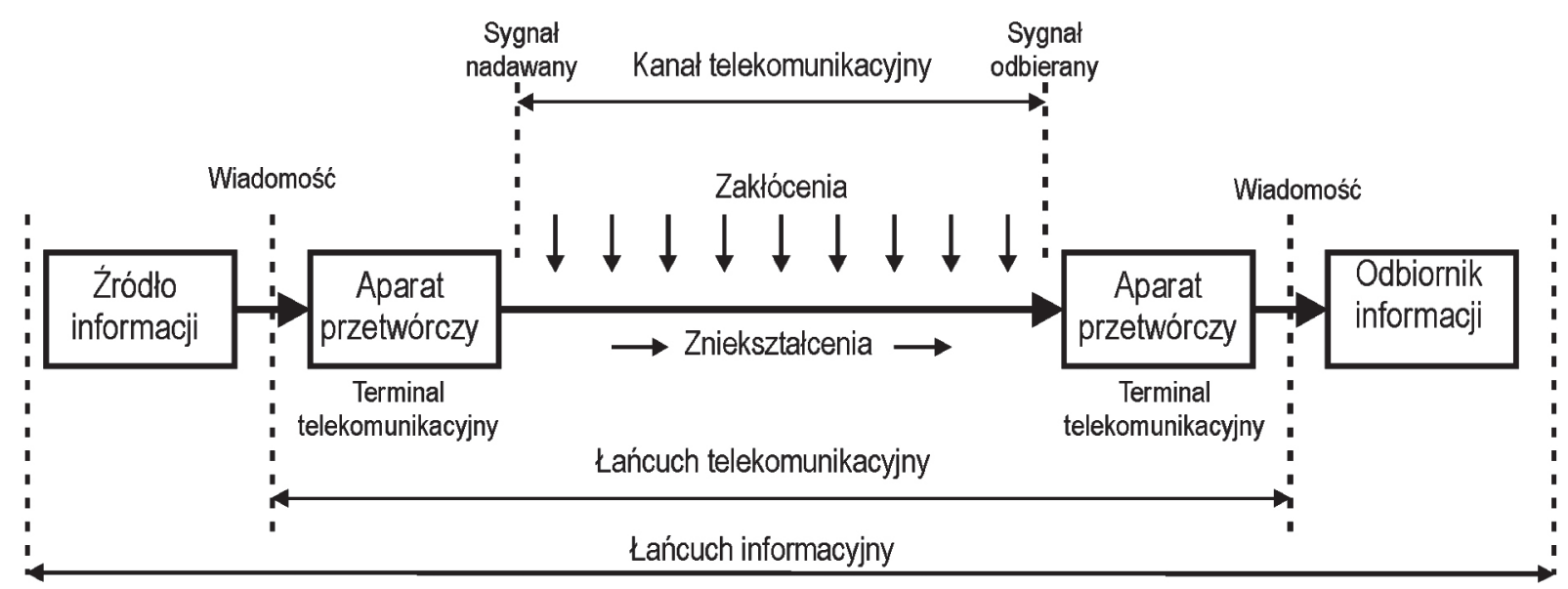

Rys. 1. Łańcuch telekomunikacyjny i informacyjny 
Rozwój technik komputerowych i związana z tym konieczność przesyłu informacji pomiędzy komputerami doprowadziła do powstania pojęcia „teleinformatyka" [3]. Na przełomie wieków rozpowszechniło się określenie skrócone, czyli telematyka. Analizując różne przypadki stosowania pojęcia telematyka, można stwierdzić, że jest ono używane głównie [4]:

- w odniesieniu do rozwiązań strukturalnych, w których elektroniczne pozyskiwanie i przetwarzanie informacji stanowią integralne elementy systemu telekomunikacyjnego,

- w odniesieniu do rozwiązań technicznych integrujących uniwersalne systemy telekomunikacyjne i informatyczne.

Telematyka to zatem określenie nowych funkcji telekomunikacyjnych związanych z dziedziną informatyki. $\mathrm{Z}$ uwagi na różnorodne zastosowania informatyki w technice termin ten występuje zazwyczaj z przymiotnikiem określającym dziedzinę zastosowania, np. telematyka transportu, telematyka medyczna czy przemysłowa. Telematyka górnicza to te systemy teleinformatyczne, które stosowane są w rozwiązaniach przeznaczonych dla górnictwa, integrujące telekomunikację $\mathrm{z}$ informatyką stosowaną $\mathrm{w}$ tych systemach.

\section{KOPALNIANY SYSTEM} TELEKOMUNIKACYJNY

W celu połączenia źródła informacji i odbiornika informacji tworzony jest łańcuch informacyjny, a wewnątrz niego łańcuch telekomunikacyjny (rys. 1), w którym ważną funkcję spełnia kopalniany serwer telekomunikacyjny. Źródła informacji to najczęściej wielkości fizyczne, które w aparacie przetwórczym zamieniane są w sygnały wprowadzane do kanału transmisyjnego wykorzystującego odpowiednie medium.

W podziemnych zakładach górniczych kanał transmisyjny może wykorzystywać następujące media transmisyjne:

- kable miedziane symetryczne lub promieniujące [5],

- kable światłowodowe [6],

- fale elektromagnetyczne (w radiokomunikacji kopalnianej) [5],

- żyły sygnalizacyjne w przewodach oponowych (np. system $\mathrm{SMoK}^{1}$ ) [7].

Kanał transmisyjny może składać z kilku odcinków wykorzystujących różne media i urządzenia transmi-

1 Skrót od nazwy „system monitorowania kombajnów” firmy SOMAR. syjne. Sygnał z wyjścia kanału transmisyjnego jest przekształcany $\mathrm{w}$ aparacie przetwórczym na wiadomość użyteczną dla odbiorcy.

Systemy telekomunikacyjne w kopalniach najczęściej służą do realizacji usług łączności przewodowej (telefonicznej, alarmowej, głośnomówiącej) [1] lub radiowej. Oprócz usług łączności głosowej w ostatnich latach w podziemnych zakładach górniczych obserwuje się duży rozwój także innych usług, przede wszystkim teleinformatycznych, które zestawiono w tabeli 1 [6].

We wszystkich usługach realizowanych za pomocą systemów telekomunikacyjnych eksploatowanych w kopalniach stosowane są rozwiązania właściwe dla systemów informatycznych. Na rysunku 2 pokazano uproszczony schemat blokowy systemu telekomunikacyjnego kopalni podziemnej [8]. Analizując ten rysunek, można zaobserwować, że informacje $\mathrm{z}$ większości dołowych systemów telekomunikacyjnych są zbierane, przetwarzane, a następnie wizualizowane w serwerach dyspozytorni zakładowych. Ogólnie można stwierdzić, że kopalniany system telekomunikacyjny realizuje usługi związane z łącznością głosową (lewa strona rys. 2) oraz właściwe dla systemów teleinformatycznych, nadzorowanych przez serwery, które procesy technologiczne obrazują na monitorach (M) w dyspozytorniach zakładowych i innych punktach decyzyjnych kopalni. Strzałki na tym rysunku obrazują zasadniczy kierunek przepływu informacji.

Poszczególne symbole w systemach związanych z łącznością kopalnianą oznaczają:

- telefony (T) i telefony sygnalizatory (TS),

- radiotelefony (RT),

- urządzenia głośnomówiące (UG),

- pulpity łączności dyspozytorskiej i alarmowej (PD, PA).

Źródła informacji właściwe dla systemów teleinformatycznych to:

- mierniki gazometrii (MG), metanomierze $\left(\mathrm{CH}_{4}\right)$ i stacje dołowe (SD) tych systemów wraz z elementami wykonawczymi, których podstawowym zadaniem jest wyłączenie zasilania energią elektryczną zagrożonych rejonów (Wz),

- geofony (G) i sejsmometry (S) systemów geofizyki górniczej,

- kamery (K) systemów monitoringu wizyjnego,

- nadajniki kanałowe (NK) systemów transmisji, głównie sygnałów dwustanowych,

- sterowniki (PLC) w podstawowych maszynach górniczych,

- zabezpieczenia cyfrowe w dołowych polach rozdzielczych średniego napięcia $(\mathrm{SN})$. 
Tabela 1

Usługi teleinformatyczne realizowane przez systemy telekomunikacyjne w kopalniach

\begin{tabular}{|c|c|}
\hline $\begin{array}{c}\text { Realizowana } \\
\text { usluga }\end{array}$ & Charakterystyka \\
\hline $\begin{array}{l}\text { Telemetria } \\
\text { (gazometria) }\end{array}$ & $\begin{array}{l}\text { Są to przede wszystkim systemy telemetryczne, monitorujące stan atmosfery kopalnianej i automatycznie } \\
\text { wyłączające urządzenia elektryczne w przypadkach zagrożeń. Jako urządzenia abonenckie w tych systemach } \\
\text { stosuje się metanomierze oraz mierniki: tlenku węgla, prędkości powietrza, temperatury, różnicy ciśnień itp. }\end{array}$ \\
\hline $\begin{array}{l}\text { Transmisja } \\
\text { sygnałów } \\
\text { dwustanowa }\end{array}$ & $\begin{array}{l}\text { W systemach tych (np. FOD) możliwa jest transmisja (jedną parą abonencką) do kilkunastu informacji } \\
\text { dwustanowych z rozproszonych w różnych wyrobiskach źródeł sygnałów (czujników, zestyków). } \\
\text { Systemy te monitorują stany pracy nawet kilkuset urządzeń górniczych. }\end{array}$ \\
\hline $\begin{array}{l}\text { Monitoring } \\
\text { (telewizja) }\end{array}$ & $\begin{array}{l}\text { Monitoring (podgląd) ważnych urządzeń górniczych oraz wyrobisk (podszybia, dworce, przesypy). Systemy te } \\
\text { wykorzystują kamery oraz sieci światłowodowe. }\end{array}$ \\
\hline $\begin{array}{l}\text { Monitoring } \\
\text { (parametrów } \\
\text { maszyn } \\
\text { i urządzeń) }\end{array}$ & $\begin{array}{l}\text { W kopalniach monitorowane są podstawowe maszyny i urządzenia górnicze. Dane z tych urządzeń mogą być } \\
\text { transmitowane na powierzchnię przy wykorzystaniu: } \\
\text { - transmisji modemowej w kablach miedzianych (np. system SMoK), } \\
\text { - sieci światłowodowych, } \\
\text { - przewodów promieniujących, systemów łączności radiowej. } \\
\text { Dane z serwerów tych systemów są archiwizowane i następnie wizualizowane w dyspozytorniach i innych } \\
\text { punktach decyzyjnych kopalni. }\end{array}$ \\
\hline $\begin{array}{l}\text { Monitoring } \\
\text { (lokalizacja, } \\
\text { identyfikacja) }\end{array}$ & $\begin{array}{l}\text { Systemy realizujące te usługi umożliwiają między innymi lokalizację strefową oraz identyfikację osób } \\
\text { lub maszyn wyposażonych w identyfikatory osobiste. } \\
\text { Lokalizacja wraz z identyfikacją jest realizowana przez czytniki identyfikatorów rozmieszczone w określonych } \\
\text { miejscach wyrobisk. }\end{array}$ \\
\hline $\begin{array}{l}\text { Wizualizacja } \\
\text { (procesów } \\
\text { technologicz- } \\
\text { nych) }\end{array}$ & $\begin{array}{l}\text { Wizualizacja, czyli graficzne metody tworzenia, analizy i przekazywania informacji o wybranych procesach } \\
\text { technologicznych, wykorzystuje: } \\
\text { - mozaikowe tablice synoptyczne w dyspozytorniach zakładowych; elementy świetlne tych tablic są sterowane } \\
\text { z systemu transmisji sygnałów dwustanowych, } \\
\text { - komputerowe systemy monitorowania i wizualizacji procesów technologicznych; dane udostępniane są } \\
\text { poprzez dedykowane dla kopalń systemy wizualizacji (np. ZEFIR, SAURON, THOR itp.), przy zastosowaniu } \\
\text { oprogramowania SCADA2. }\end{array}$ \\
\hline
\end{tabular}

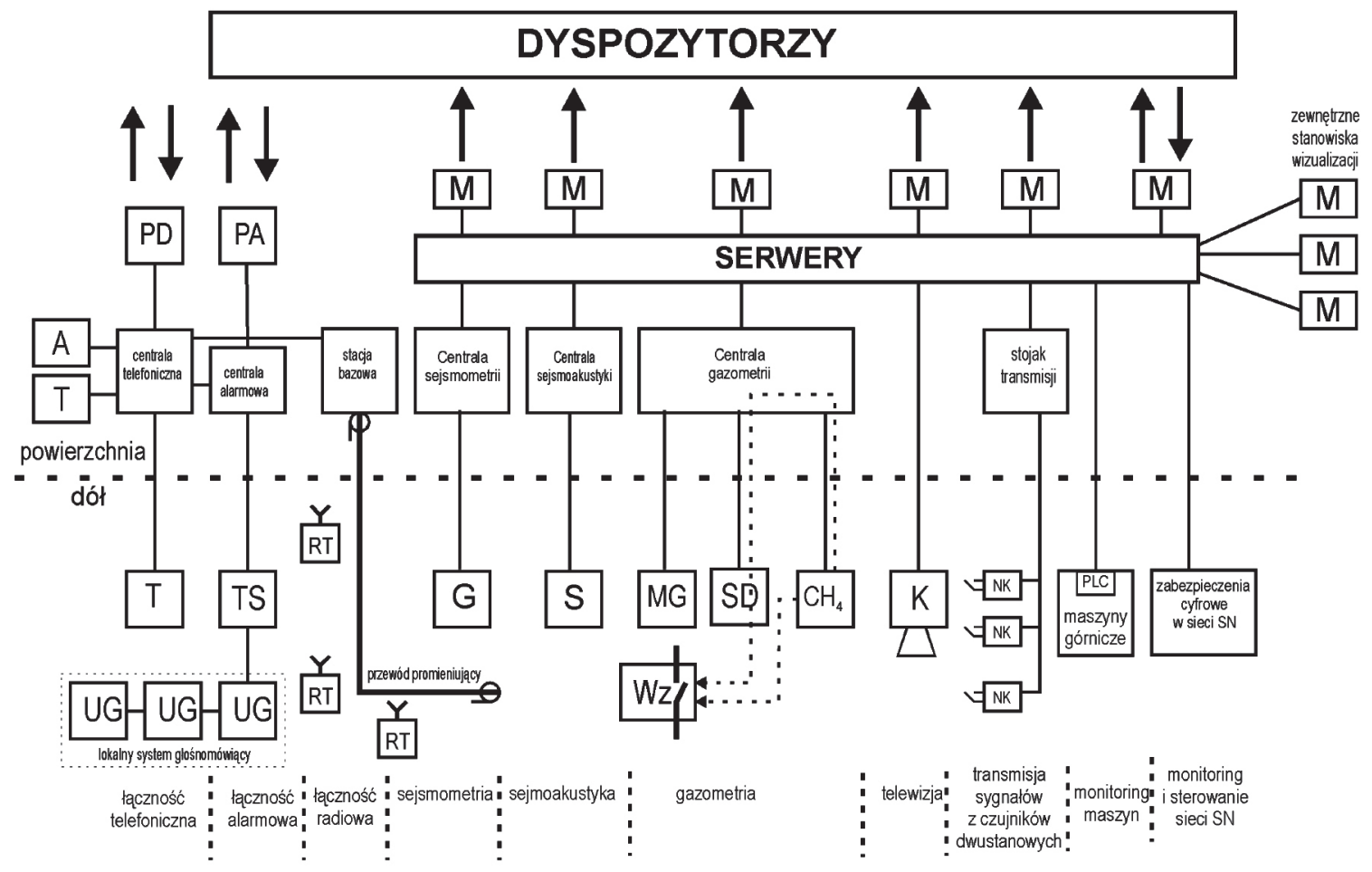

Rys. 2. Uproszczony schemat typowego systemu telekomunikacyjnego w kopalni podziemnej

\footnotetext{
2 SCADA - ang. supervisory control and data acquisition.
} 
Należy zwrócić uwagę na to, że środowisko techniczne podziemi kopalń stawia nietypowe wymagania (ograniczenia) systemom telekomunikacyjnym, co także znajduje odzwierciedlenie w budowie i strukturach systemów telematycznych w kopalniach. Zasadnicze ograniczenia środowiskowe w zakresie możliwości szerszego wykorzystania wielu nowych rozwiązań stosowanych w systemach telematycznych zostały przedstawione w tabeli 2 [9].

\section{TELEMATYKA \\ W KOPALNIANEJ ŁACCZNOŚCI TELEFONICZNEJ}

Zasadniczą funkcją każdej kopalnianej centrali telefonicznej jest stworzenie możliwości komutacji przyłączonych do niej terminali abonentów. Zwiększenie funkcjonalności cyfrowych central telefonicznych oraz zmiany przepisów w tym zakresie [10-12] spowodowały dużą rozbudowę ich części sterującej, prowadząc do stworzenia w centrali wewnętrznej, czasem bardzo rozbudowanej, wydzielonej sieci komputerowej zawierającej szereg komputerów wraz z odpowiednim oprogramowaniem, realizujących takie funkcje, jak: nagrywanie rozmów, poczta głosowa, książka telefoniczna, automatyczne pomiary linii transmisyjnych, rozgłaszanie komunikatów, identyfikacja abonentów, rejestracja i taryfikacja rozmów telefonicznych, edycja baz danych itp. W wyniku takiej rozbudowy centrala telefoniczna stała się serwerem telekomunikacyjnym, ponieważ oprócz funkcji łączeniowych właściwych dla centrali telefonicznej pełni również wiele funkcji właściwych dla systemów informatycznych [13].

Niezmiernie istotną rolę odgrywają serwery telekomunikacyjne $\mathrm{w}$ procesach integracji systemów łączności z systemami alarmowania, gazometrii i połączeń serwerów telekomunikacyjnych kopalń łączonych i wieloruchowych [6].

Tabela 2

Podstawowe ograniczenia w stosowaniu systemów telematycznych w kopalniach

\begin{tabular}{|c|c|}
\hline Ograniczenie & Charakterystyka \\
\hline Przeciwwybuchowość & $\begin{array}{l}\text { W kopalniach zagrożonych wybuchem metanu i/lub pyłu węglowego urządzenia dołowe oraz interfejsy } \\
\text { dołowe linii telekomunikacyjnych powinny być przeciwwybuchowe. Urządzenia dołowe systemów } \\
\text { telekomunikacyjnych powinny mieć budowę iskrobezpieczną lub być bezpieczne optycznie (cecha „opis” } \\
\text { wg PN-EN 60079-28) i umożliwiać pracę w warunkach dowolnej koncentracji metanu. }\end{array}$ \\
\hline $\begin{array}{l}\text { Stopień ochrony } \\
\text { obudowy urządzeń }\end{array}$ & $\begin{array}{l}\text { Z uwagi na wilgotność, zasolenie i obecność pyłów urządzenia telekomunikacyjne oraz urządzenia } \\
\text { współpracujące z tymi systemami stosowane w wyrobiskach powinny posiadać stopień ochrony obudo- } \\
\text { wy minimum IP54. }\end{array}$ \\
\hline Struktura wyrobisk & $\begin{array}{l}\text { Małe poprzeczne wymiary wyrobisk korytarzowych (kilka metrów) w stosunku do ich wymiarów po- } \\
\text { dłużnych (do kilku kilometrów); rozległość wyrobisk i konieczność stosowania drzewiastej struktury } \\
\text { sieci telekomunikacyjnych. }\end{array}$ \\
\hline $\begin{array}{l}\text { Środowisko } \\
\text { elektromagnetyczne }\end{array}$ & $\begin{array}{l}\text { W wyrobiskach występuje duże nagromadzenie (w ograniczonych przestrzeniach) sieci i urządzeń elek- } \\
\text { troenergetycznych o bardzo dużych mocach; występują trudności ze skutecznym rozdziałem uziomów } \\
\text { elektroenergetycznych (w tym SUPO) i telekomunikacyjnych; sieci telekomunikacyjne w kablach opan- } \\
\text { cerzonych oraz elektroenergetyczne na długich odcinkach wyrobisk są prowadzone równolegle w nie- } \\
\text { wielkiej odległości ograniczonej przede wszystkim wymiarami poprzecznymi wyrobisk. }\end{array}$ \\
\hline $\begin{array}{l}\text { Ograniczona ciagłość } \\
\text { zasilania dołowych } \\
\text { urządzeń } \\
\text { telekomunikacyjnych } \\
\text { z sieci } \\
\text { elektroenergetycznej }\end{array}$ & $\begin{array}{l}\text { Ciagłość zasilania tych urządzeń jest ograniczona przez: } \\
\text { - planowe wyłączenia w sieci elektroenergetycznej (np. przeprowadzanie napraw) oraz okresowe testo- } \\
\text { wanie układów wyłączeń urządzeń elektroenergetycznych realizowanych przez systemy gazometrii, } \\
\text { - nieplanowe wyłączenia wywołane zadziałaniem zabezpieczeń elektroenergetycznych oraz metanome- } \\
\text { trycznych. } \\
\text { Przekroczenie progu alarmowego metanomierza w wyrobisku powoduje automatyczne wyłączenie ener- } \\
\text { gii elektrycznej w danym rejonie. Wzrost stężenia tlenku węgla czy brak określonego minimalnego prze- } \\
\text { pływu powietrza również może być przyczyną alarmów lub wyłączeń energii elektrycznej. }\end{array}$ \\
\hline
\end{tabular}

Na rysunku 3 przedstawiono uproszczony schemat blokowy jednosekcyjnego serwera telekomunikacyjnego DGT IPnova, najpowszechniej stosowanego w polskich podziemnych zakładach górniczych, w którym zaznaczono najprostszą wydzieloną sieć tele- informatyczną LAN [1]. Do przełącznika tej sieci oprócz jednostek sterujących (JS) przyłączone są serwery: systemu nagrywania rozmów (NetCRR), usług dodatkowych (SUD), edycji baz danych (KBDed), zdalnego nadzoru (KZN) itp. Serwer ten może 


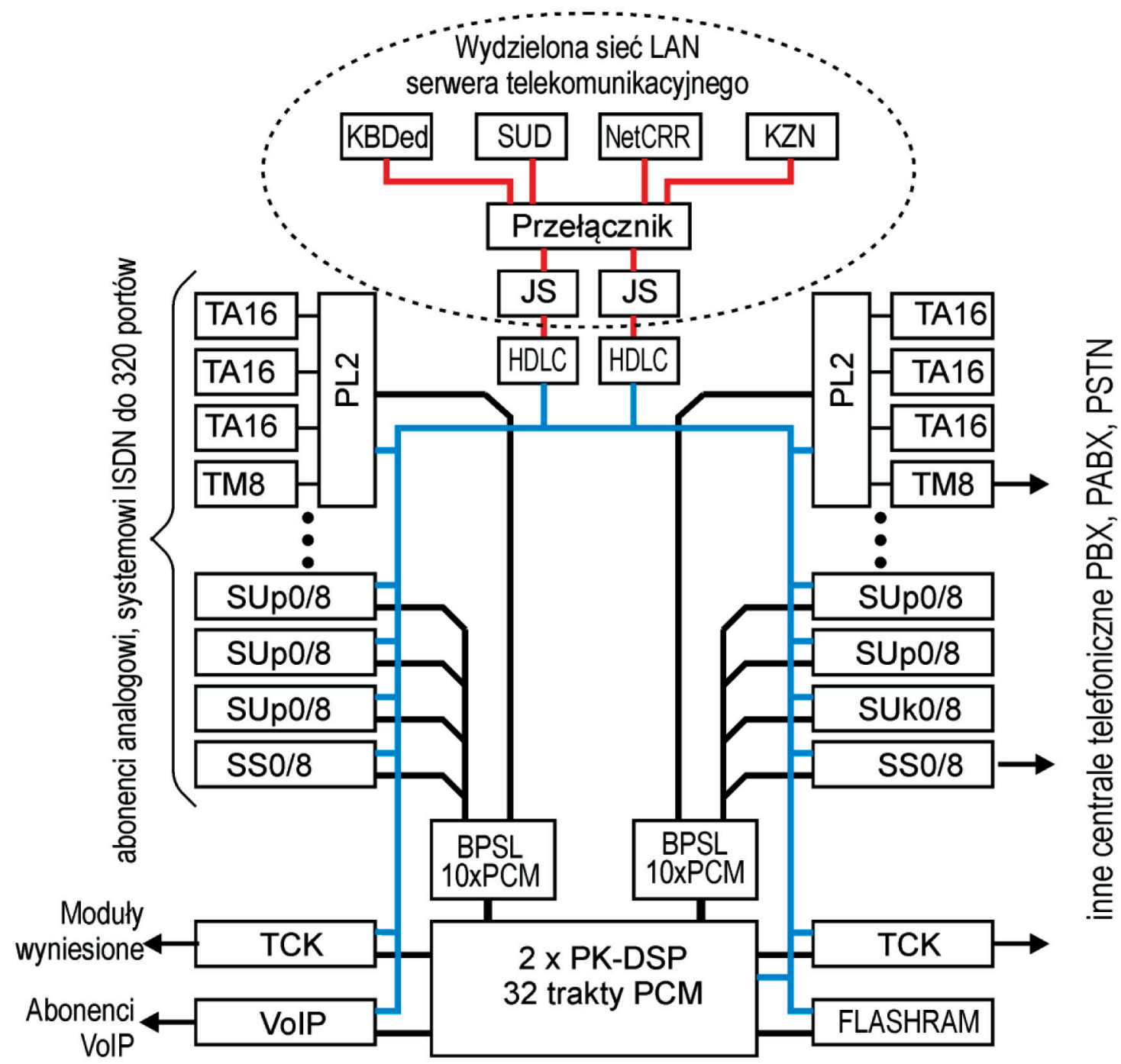

Rys. 3. Ogólna architektura jednosekcyjnego serwera telekomunikacyjnego DGT IPnovaPL2 procesory liniowe, PK-DSP pole komutacyjne, FLASHRAM procesor sygnatów tonowych $i$ komunikatów stownych, BPSL bufor liniowy

obsługiwać nie tylko abonentów wyposażonych w telefony analogowe (TA16) czy cyfrowe różnych standardów (SUp0, SS0, SUk0), lecz także abonentów VoIP. Serwery w sieci LAN mogą pełnić jedną z dwóch zasadniczych funkcji informatycznych:

- w zakresie sprzętowym - są to komputery przemysłowe świadczące określonego rodzaju usługi, sprowadzające się zazwyczaj do udostępniania swoich zasobów innym komputerom lub pośredniczące w przekazywaniu danych między komputerami,

- w zakresie programowym - jest to zainstalowane specyficzne oprogramowanie (program, baza danych) świadczące usługi na rzecz innych urządzeń czy systemów (np. gazometrycznych, wizualizacji), przyłączonych do tej sieci LAN w kopalni.

Stosunkowo nowym sposobem realizacji łączności telefonicznej w kopalniach jest również wykorzystywanie sieci komputerowych, co zostało nazwane skró- tem VoIP ${ }^{3}$. W tego rodzaju sieciach występuje transmisja pakietów zawierających głos w postaci cyfrowej. Współczesne serwery telekomunikacyjne kopalń umożliwiają podłączenie do systemu łączności ogólnokopalnianej abonentów telefonii VoIP za pośrednictwem karty VoIP wyposażonej w gniazdo Ethernet. Do wydzielonej sieci LAN (lub do portów cyfrowych serwera telekomunikacyjnego DGT IPnova) można przyłączyć także urządzenia teletransmisyjne innych kopalnianych systemów telekomunikacyjnych (gazometrii, transmisji danych, wizualizacji, alarmowania).

\section{TELEMATYKA W SYSTEMACH MONITORINGU}

Pierwsze systemy monitoringu środowiska technicznego kopalń podziemnych stosuje się od połowy

\footnotetext{
3 VoIP - ang. Voice over Internet Protocol.
} 
lat siedemdziesiątych ubiegłego wieku w dyspozytorniach metanometrycznych (centrale CTT63/40U). W tym samym czasie rozpowszechnił się również monitoring dwustanowy maszyn i urządzeń górniczych (system CTT-32). Miał on charakter obserwacji tzw. stanów skrajnych (np. praca/postój, otwarty/zamknięty, pełny/niepełny itp.) [7, 14]. Od ponad dwudziestu lat kombajn górniczy wyposażany jest w komputerowy układ sterowania wraz z systemem rejestracji i archiwizacji zdarzeń. Zdalny (z powierzchni) monitoring maszyn i urządzeń górniczych rozpoczął się na przełomie wieków wdrożeniem w kopalni Bogdanka systemu SMoK z modemowym systemem transmisji informacji do dyspozytorni zakładowej. W dyspozytorniach kopalń są więc obecnie dostępne dwa rodzaje informacji o stanie pracy maszyn lub urządzeń:

- informacje podstawowe - monitoring dwustanowy, uzyskiwany najczęściej z systemów wielokrotnej transmisji sygnałów (np. FOD, UTS, CTT-32),

- informacje zaawansowane (sygnały analogowe) uzyskiwane ze sterowników maszyn lub urządzeń górniczych, a także zabezpieczeń cyfrowych w rozdzielnicach, czy też z systemów gazometrycznych.

W latach dziewięćdziesiątych XX wieku upowszechnił się system ZEFIR, który był pierwszym dyspozytorskim systemem wizualizacji wykorzystującym komputery osobiste klasy IBM PC, pracujące pod kontrolą systemu DOS. System ten początkowo pobierał dane z systemów transmisji dwustanowej i dokonywał ich wizualizacji. ZEFIR (po wielu modyfikacjach technicznych i programowych) jest eksploatowany do dzisiaj i wyznacza wiele nieformalnych standardów w zakresie funkcjonowania komputerowych systemów monitoringu i wizualizacji w kopalniach [7].

Obecnie dla bieżącego nadzoru maszyn i urządzeń górniczych, a także sieci elektroenergetycznych stosuje się systemy monitorowania wykorzystujące najczęściej oprogramowanie typu SCADA. Podstawowymi zadaniami takich systemów monitorowania są [6, 7, 14]:

- zbieranie i archiwizacja sygnałów z monitorowanych urządzeń, np. wyników pomiarów,

- wizualizacja stanu monitorowanych urządzeń w punktach nadzoru,

- zdalne sterowanie maszynami, a także wyłącznikami w rozdzielnicach,

- alarmowanie o nieprawidłowych ich stanach,

- sporządzanie raportów (np. dla potrzeb nadzoru produkcji).

Obecnie podstawowym medium transmisyjnym w kopalniach podziemnych są kable symetryczne miedziane. W typowej kopalni średnio wykorzystuje się ponad 1000 par [7, 9]. Wynika to $\mathrm{z}$ faktu, że wiele urządzeń końcowych (metanomierze, telefony i telefony sygnalizatory alarmowe) wymaga zasilania cen- tralnego z powierzchni. W systemach telematycznych pasmo częstotliwości akustycznych jest wykorzystywane w transmisji sygnałów dwustanowych (FOD-900, UTS) z dostępem po drodze, w gazometrii, gdzie wykorzystuje się głównie modemy telefoniczne dla linii dzierżawionych, a w niektórych systemach transmisję częstotliwościową (do $12 \mathrm{kHz}$ ), w sejsmometrii i sejsmoakustyce oraz do monitorowania maszyn i urządzeń górniczych z wykorzystaniem wąskopasmowych modemów telefonicznych dla linii dzierżawionych. Modemy telefoniczne w kopalniach potrafią pracować z przepływnością do $33600 \mathrm{~kb} / \mathrm{s}$ w liniach symetrycznych o średnicy żył $0,8 \mathrm{~mm}$ [15].

Pasma wyższych częstotliwości w podziemnych zakładach górniczych mogą być eksploatowane w systemach transmisji danych (np. jako łącza RS485 lub wykorzystujące protokół Lon Works), niestety tylko na stosunkowo krótkie odległości (zasięg transmisji do $2 \mathrm{~km}$ ), natomiast w jeszcze wyższych pasmach częstotliwości sporadycznie stosuje się modemy szerokopasmowe (np. modemy SHDSL firmy WESTERMO) [15].

Ograniczenia związane $\mathrm{z}$ rozległością wyrobisk, koniecznością zapewnienia iskrobezpieczeństwa w dołowych sieciach teletransmisyjnych i możliwe do uzyskania w kablach miedzianych maksymalne szybkości transmisji sprawiły, że w kopalniach równolegle do sieci miedzianych, buduje się sieci światłowodowe, wykorzystywane przede wszystkim w systemach monitorowania maszyn i urządzeń górniczych.

Właściwości poszczególnych mediów transmisyjnych zestawiono w tabeli 3 [15].

Należy zwrócić uwagę, że o możliwym zakresie monitorowania maszyn i urządzeń górniczych decyduje przede wszystkim współczesna telematyka, czyli zainstalowane $\mathrm{w}$ nich inteligentne urzadzenie elektroniczne $\left(\mathrm{IED}^{4}\right)$. Obecność urządzeń IED umożliwia uzyskanie za pomocą pomiarów wielu szczegółowych informacji o wartościach mierzonych wielkości elektrycznych (prąd, napięcie, moc, energia elektryczna) oraz umożliwia także zdalne ich sterowanie. Analiza obecnego stanu urządzeń IED zainstalowanych w kopalniach podziemnych wykazała, że w kopalniach stosowanych jest równolegle kilka różnych systemów wizualizacji. Jedne $\mathrm{z}$ nich wykorzystuje dyspozytor główny, inne dyspozytor metanometrii, a jeszcze inne są stosowane w dyspozytorniach energomechanicznych czy w sterowaniu transportem.

W tabeli 4 (w kolejności alfabetycznej) przedstawiono przykładowe dyspozytorskie systemy wizualizacji stosowane w polskich kopalniach $[8,14]$.

\footnotetext{
4 IED - inteligentne urządzenie elektroniczne; skrót od określenia intelligent electronic devices; jest to urządzenie zawierające co najmniej jeden procesor umożliwiający komunikację z zewnętrznymi źródłami danych (np. elektronicznych mierników, zabezpieczeń cyfrowych, sterowników).
} 
Tabela 3

Porównanie właściwości mediów transmisyjnych dla kopalń podziemnych

\begin{tabular}{|c|c|c|c|c|}
\hline & $\begin{array}{l}\text { Kable miedziane } \\
\text { symetryczne }\end{array}$ & $\begin{array}{c}\text { Kable miedziane } \\
\text { promieniujące }\end{array}$ & $\begin{array}{c}\text { Kable } \\
\text { światlowodowe }\end{array}$ & $\begin{array}{l}\text { Lącza } \\
\text { radiowe }\end{array}$ \\
\hline Zasięg & $\begin{array}{c}\text { od } 100 \mathrm{~m} \text { dla } 1 \mathrm{~GB} / \mathrm{s} \\
\text { do ponad } 10 \mathrm{~km} \\
\text { dla pasma telefonicznego }\end{array}$ & $\begin{array}{c}\text { do } 500 \mathrm{~m} \text {, konieczność } \\
\text { budowy infrastruktury } \\
\text { ze wzmacniakami }\end{array}$ & $\begin{array}{l}\text { do kilkudziesięciu } \\
\text { kilometrów, } \\
\text { do } 1 \mathrm{~Gb} / \mathrm{s}\end{array}$ & $\begin{array}{c}\text { kilkaset metrów, } \\
\text { niezbędna infrastruktura } \\
\text { dostępowa }\end{array}$ \\
\hline Zdalne zasilanie & tak & tak & nie; tak (kable hybrydowe) & nie \\
\hline Wpływ zlącz & pomijalny & niewielki & istotny & nie dotyczy \\
\hline Przeplywność & $\begin{array}{c}\text { do } 1 \mathrm{~Gb} / \mathrm{s}, \text { im wyższa } \\
\text { częstotliwość } \\
\text { tym mniejszy zasięg }\end{array}$ & $\begin{array}{c}\text { do kilkuset megaherców } \\
\text { (modemy, } \\
\text { szerokopasmowe) }\end{array}$ & do $1 \mathrm{~Gb} / \mathrm{s}$ & $\begin{array}{l}\text { do kilkudziesięciu } \\
\text { megabitów na sekundę }\end{array}$ \\
\hline $\begin{array}{l}\text { Technologia } \\
\text { lączenia }\end{array}$ & latwa & łatwa - wymaga złącz & $\begin{array}{l}\text { trudna - wymaga } \\
\text { zaawansowanych narzędzi } \\
\text { (spajanie włókien) }\end{array}$ & nie dotyczy \\
\hline
\end{tabular}

Tabela 4

Przykładowe systemy nadzoru, sterowania i wizualizacji stosowane w kopalniach

\begin{tabular}{|c|c|c|}
\hline $\begin{array}{c}\text { Nazwa } \\
\text { systemu }\end{array}$ & Producent & Uwagi \\
\hline DEMKop & SOMAR & $\begin{array}{l}\text { Kopalniany system wizualizacji przeznaczony w szczególności dla dyspozytorni energomechanicznych } \\
\text { zakładów górniczych jako oprogramowanie narzędziowe; rozwiązania sprzętowe to system SMoK. }\end{array}$ \\
\hline e-kopalnia & FAMUR & $\begin{array}{l}\text { System zdalnego nadzoru maszyn górniczych (zbiór rozwiązań teleinformatycznych, sprzętowych } \\
\text { i narzędzi pomiarowych). Elementy tego systemu to: urządzenia sterowania (np. FAMAC: MRS, } \\
\text { OPTI, DMP), przeciwwybuchowy sprzęt informatyczny (np. serwer, stacja lokalna LS, komputer } \\
\text { MPC I) oraz systemy diagnostyczne sprzętowe, a także programowe. }\end{array}$ \\
\hline EMAC & $\begin{array}{l}\text { ENERGO } \\
\text { TEST }\end{array}$ & $\begin{array}{l}\text { System dla sieci elektroenergetycznych; współpracuje ze sterownikami urządzeń elektroenergetycznych } \\
\text { PLC różnych firm i innymi zabezpieczeniami wyposażonymi w jawny protokół komunikacyjny. }\end{array}$ \\
\hline EP7-SMP & ELPRO7 & System monitorowania pompowni dołowych firmy ELPRO. \\
\hline $\begin{array}{l}\text { eSPiM } \\
\text { CSBiRE }\end{array}$ & WINUEL & $\begin{array}{l}\text { Elektroniczny system pomiarowo-rozliczeniowy energii; system wizualizacji raportowania, analiz } \\
\text { symulacyjnych i planowania oraz zarządzania zużyciem energii elektrycznej; stosowany w KGHM. }\end{array}$ \\
\hline MonSteer-D & Tranz-Tel & $\begin{array}{l}\text { System nadzoru dyspozytorskiego; oprogramowanie narzędziowe; rozwiązanie sprzętowe } \\
\text { to np. system FOD. }\end{array}$ \\
\hline SAURON & RNT & $\begin{array}{l}\text { System wizualizacji SAURON posiada interfejsy do komunikacji z IED urządzeń górniczych } \\
\text { oraz dedykowane aplikacje programowe, takie jak np.: Pompownie, Sieć } 6 \text { kV, Odstawa, } \\
\text { Ściany, Przodki, Skipy, Klimatyzacja. }\end{array}$ \\
\hline SD-2000 & EMAG & Dyspozytorski system wizualizacji; oprogramowanie narzędziowe. \\
\hline Smart Wall & $\begin{array}{l}\text { Elgór+ } \\
\text { Hansen }\end{array}$ & $\begin{array}{l}\text { System sterowania, monitoringu maszyn i urządzeń górniczych. System posiada elementy sprzętowe } \\
\text { (np. ognioszczelny komputer EH-O/06, pulpit sterowniczy EH-O/01, separator EH-O/03) } \\
\text { oraz programowe (np. KESSA-ATON, EH-WallView, EH-MineView). }\end{array}$ \\
\hline SP3 & HASO & System prezentacji procesów przemysłowych (SP3); oprogramowanie narzędziowe. \\
\hline $\mathrm{SW} \mu \mathrm{P}$ & HASO & Komputerowy system wspomagania dyspozytora metanometrii; oprogramowanie narzędziowe. \\
\hline $\begin{array}{l}\text { SYNDIS } \\
(\mathrm{RV})\end{array}$ & $\begin{array}{l}\text { MIKRO } \\
\text { NIKA }\end{array}$ & $\begin{array}{l}\text { System nadzoru, doradztwa i sterowania instalacjami przemysłowymi; dyspozytorski system } \\
\text { monitorowania i kontroli pracy systemu elektroenergetycznego kopalni stosowany jest w KGHM. }\end{array}$ \\
\hline THOR & SEVITEL & $\begin{array}{l}\text { System dyspozytorski: wizualizacji, monitoringu, archiwizacji, raportowania i sterowania; } \\
\text { oprogramowanie narzędziowe. }\end{array}$ \\
\hline WIZAS & $\begin{array}{l}\text { Becker } \\
\text { Warkop }\end{array}$ & System wizualizacji maszyn ścianowych z dedykowanymi sterownikami firmy BECKER. \\
\hline $\begin{array}{l}\text { WIZCON } \\
\text { Superwizor }\end{array}$ & $\begin{array}{l}\text { Wizcon } ® \\
\text { Systems } \\
\text { SABUR }\end{array}$ & $\begin{array}{l}\text { Dyspozytorski system kontroli parametrów produkcji i bezpieczeństwa z modułem wizualizacji } \\
\text { WIZCON; oprogramowanie przemysłowe pozwalające na zarządzanie, monitoring i sterowanie } \\
\text { procesami technologicznymi za pomocą przeglądarki internetowej. }\end{array}$ \\
\hline ZEFIR & PRUNELLA & $\begin{array}{l}\text { Najpowszechniej stosowany w kopalniach dyspozytorski system wizualizacji przeznaczony } \\
\text { dla dyspozytorni zakładowych, dynamiczna tablica synoptyczna; oprogramowanie narzędziowe. }\end{array}$ \\
\hline
\end{tabular}




\section{PODSUMOWANIE}

Telematyka w systemach monitoringu rozwija się obecnie najszybciej ze wszystkich innych usług telekomunikacyjnych w kopalniach. Monitoring maszyn, urządzeń i środowiska zawsze wiąże się jednak z koniecznością instalacji nowych sterowników oraz modyfikacją wyposażenia i oprogramowania sterowników już istniejących, a także budową światłowodowych linii telekomunikacyjnych w magistralnej sieci kablowej [15].

Wprowadzenie monitoringu w nowych obszarach technologicznych w kopalniach powinno być jednak poprzedzone analizą, która uwzględni zarówno koszty telematyki, jak i jej znaczenie dla całości nadzorowanego procesu technologicznego w kopalni czy diagnostyki poszczególnych ważnych urządzeń.

Monitoring w kopalni należy rozpocząć od wyposażenia maszyn górniczych $w$ inteligentne urządzenia elektroniczne (IED) i takie układy automatyki, które umożliwią ich zdalne sterowanie.

Wzrost wydajności w kopalni można osiągnąć kilkoma sposobami, z których najtańsze to m.in.:

- zwiększenie efektywnego czasu pracy eksploatowanych w zakładzie górniczym maszyn i urządzeń elektrycznych,

- minimalizacja przestojów, czyli czasu traconego na niekontrolowane awarie maszyn i urządzeń oraz skrócenie czynności międzyoperacyjnych (np. przekładki maszyn).

Cele te można osiągnąć, wprowadzając w kopalniach nowoczesne systemy telematyczne. W kopalniach nie powinno dochodzić do awarii. Stąd należy kłaść duży nacisk na bieżące monitorowanie urządzeń elektrycznych przede wszystkim pod kątem wcześniejszego wykrywania nieprawidłowości w ich pracy oraz należytego przygotowania planowanego remontu.

Należy zdać sobie sprawę, że z powodu konieczności instalacji w wyrobiskach urządzeń łączności telefonicznej, sygnalizatorów systemów alarmowania i czujników systemów gazometrycznych kable miedziane są i nadal będą instalowane we wszystkich korytarzowych wyrobiskach dołowych. Nie moga one jednak stanowić zasadniczego elementu systemu tele- transmisyjnego w systemach telematycznych. Do monitorowania ważnych obiektów energomechanicznych należy wykorzystywać w kopalniach sieci światłowodowe.

\section{Literatura}

[1] Miśkiewicz K., Wojaczek A.: Telekomunikacja w górnictwie. Systemy łaczności telefonicznej, alarmowej i głośnomówiace, Wydawnictwo Politechniki Śląskiej, Gliwice 2018.

[2] Ustawa z dnia 16 lipca 2004 r., Prawo telekomunikacyjne, Dz.U. z 2004 r., nr 171, poz. 1800.

[3] Noris M.: Teleinformatyka, Wydawnictwo Komunikacji i Łączności, Warszawa 2002.

[4] Wydro K.B.: Telematyka - znaczenie i definicje terminu, „Telekomunikacja i techniki informacyjne” 2005, 1-2: 116-127.

[5] Miśkiewicz K., Wojaczek A.: Systemy radiokomunikacji z kablem promieniujacym, Wydawnictwo Politechniki Śląskiej, Gliwice 2010.

[6] Miśkiewicz K., Wojaczek A., Wojtas P.: Systemy dyspozytorskie kopaln podziemnych i ich integracja. Wybrane problemy, Wydawnictwo Politechniki Śląskiej, Gliwice 2011.

[7] Dyczko A., Wojaczek A. (red.): Systemy telekomunikacyjne, monitoring $i$ wizualizacja podziemnej eksploatacji złóż, Monografia SEP. Wydawnictwo Fundacji dla AGH, Kraków 2011.

[8] Wojaczek A., Wojaczek A.: Systemy monitoringu $w$ kopalni podziemnej, „Systemy Wspomagania w Inżynierii Produkcji” 2016, 1: 523-536.

[9] Wojaczek A.: Wpływ środowiska technicznego kopalń podziemnych na transmisje sygnałów $w$ dołowych sieciach telekomunikacyjnych, Wydawnictwo Politechniki Śląskiej, Gliwice 2014.

[10] Ustawa z dnia 9 czerwca 2011 r. Prawo geologiczne i górnicze. Obwieszczenie Marszałka Sejmu Rzeczypospolitej Polskiej z dnia 1 lipca 2016 r. w sprawie ogłoszenia jednolitego tekstu ustawyPrawo geologiczne i górnicze, Dz.U. z 2016 r., poz. 1131.

[11] Rozporzadzenie Ministra Energii z dnia 23 listopada 2016 r. w sprawie szczegółowych wymagań dotyczacych prowadzenia ruchu podziemnych zakładów górniczych, Dz.U. z 2017 r., poz. 1118.

[12] Rozporządzenie Rady Ministrów z dnia 30.04.2004 r. w sprawie dopuszczania wyrobów do stosowania w zakładach górniczych, Dz.U. z 2004 r., nr 99, poz. 1003.

[13] Wojaczek A.: Łącze, sieć serwer w telekomunikacji górniczej, „Mechanizacja i Automatyzacja Górnictwa” 2014, 3: 53-59.

[14] Wojaczek A., Dyczko A. (red.): Monitoring wybranych procesów technologicznych $w$ kopalniach podziemnych, Wydawnictwo Katedry Elektryfikacji i Automatyzacji Górnictwa Politechniki Śląskiej, Gliwice 2015.

[15] Wojaczek A., Miśkiewicz K.: Problemy transmisji w kopalnianych systemach telekomunikacyjnych, „Mechanizacja i Automatyzacja Górnictwa” 2013, 7: 5-12.

dr hab. inż. ANTONI WOJACZEK, prof. Pol. Śl. Katedra Elektrotechniki i Automatyki Przemystowej Wydziat Górnictwa i Geologii Politechnika Ślaska ul. Akademicka 2, 44-100 Gliwice awojaczek@polsl.pl 